\title{
Article \\ Effect of Chitosan Nanoemulsion on Enhancing the Phytochemical Contents, Health-Promoting Components, and Shelf Life of Raspberry (Rubus sanctus Schreber)
}

\author{
Shirin Rahmanzadeh Ishkeh ${ }^{1}$, Habib Shirzad ${ }^{1, *}$, Mohammadreza Asghari ${ }^{1}{ }^{\mathbb{D}}$, Abolfazl Alirezalu ${ }^{1} \mathbb{D}$, \\ Mirian Pateiro ${ }^{2}$ a and José M. Lorenzo ${ }^{2,3, * \mathbb{D}}$ \\ 1 Department of Horticultural Sciences, Faculty of Agriculture, Urmia University, \\ Urmia P.O. Box 165-5715944931, Iran; shirinrahmanzade@yahoo.com (S.R.I.); m.asghari@urmia.ac.ir (M.A.); \\ a.alirezalu@urmia.ac.ir (A.A.) \\ 2 Centro Tecnológico de la Carne de Galicia, Parque Tecnológico de Galicia, rúa Galicia n ${ }^{\circ}$, San Cibrao das \\ Viñas, 32900 Ourense, Spain; mirianpateiro@ceteca.net \\ 3 Área de Tecnología de los Alimentos, Facultad de Ciencias de Ourense, Universidad de Vigo, \\ 32004 Ourense, Spain \\ * Correspondence: h.shirzad@urmia.ac.ir (H.S.); jmlorenzo@ceteca.net (J.M.L.)
}

Citation: Ishkeh, S.R.; Shirzad, H.; Asghari, M.; Alirezalu, A.; Pateiro, M.; Lorenzo, J.M. Effect of Chitosan Nanoemulsion on Enhancing the Phytochemical Contents, HealthPromoting Components, and Shelf Life of Raspberry (Rubus sanctus Schreber). Appl. Sci. 2021, 11, 2224. https://doi.org/10.3390/ app11052224

Academic Editor:

Theodoros Varzakas

Received: 11 February 2021

Accepted: 1 March 2021

Published: 3 March 2021

Publisher's Note: MDPI stays neutral with regard to jurisdictional claims in published maps and institutional affiliations.

Copyright: (c) 2021 by the authors. Licensee MDPI, Basel, Switzerland. This article is an open access article distributed under the terms and conditions of the Creative Commons Attribution (CC BY) license (https:/ creativecommons.org/licenses/by/ $4.0 /)$
Abstract: Due to high water content and perishability, the raspberry fruit is sensitive to postharvest fungal contamination and postharvest losses. In this study, chitosan was used as an edible coating to increase the storage of raspberries, and nanotechnology was used to increase chitosan efficiency. The fruit was treated with an emulsion containing nanoparticles of chitosan (ECNPC) at 0, 2.5, and $5 \mathrm{~g} \mathrm{~L}^{-1}$, and stored for $9 \mathrm{~d}$. Decay extension rate, fruit phytochemical contents, including total phenolics, flavonoids, and anthocyanin content, phenylalanine ammonia-lyase (PAL), and guaiacolperoxidase enzymes and antioxidant activity, and other qualitative properties were evaluated during and at the end of storage. After $9 \mathrm{~d}$ of storage, the highest amounts of phenolics compounds, PAL enzyme activity, and antioxidant activity were observed in fruit treated with ECNPC at $5 \mathrm{~g} \mathrm{~L}^{-1}$. The highest levels of total phenol, PAL enzyme activity, and antioxidant activity were $57.53 \mathrm{~g} \mathrm{~L}^{-1}$, $118.88 \mu \mathrm{mol} / \mathrm{min}$ trans-cinnamic acid, and $85.16 \%$, respectively. ECNPC can be considered as an effective, safe, and environmentally friendly method for enhancing fruit phytochemical contents, postharvest life, and health-promoting capacity.

Keywords: edible coating; nanoemulsion; guaiacol peroxidase; shelf life; anthocyanins; phenylalanine ammonia-lyase

\section{Introduction}

Fruit and vegetables play an important role in improving human health. Among different food crops, colorful fruit and berries, including raspberries, are rich in different antioxidant and anti-stress compounds with powerful anti-cancer and anti-inflammatory attributes [1-3]. Rubus sanctus Schreber is a member of the family Rosaceae and its subfamily is Rosoideae. Berry fruits contain abundant phenolic compounds such as phenolic acids, flavonoids, and anthocyanins, and they are an excellent source of antioxidants such as vitamins (A, and ascorbic acid). In addition, they are useful for the treatment of various diseases, particularly diabetic patients [4].

However, this fruit is very perishable and undergoes substantial changes in antioxidant and phytochemical contents during postharvest storage and handling stages. Water loss, softening, decay extension, and metabolic activities are the main causes for a decrease in fruit quality, phytochemical contents, and marketability [5]. The content of bioactive compounds in Rubus depends chiefly on the sowing method, variety, harvest season, and postharvest handling. Several investigations indicate that organic farming systems followed by postharvest conditions have a considerable influence on the quality of berry 
fruit production [6]. The decrease in nutritional properties and marketability of fruit and vegetables during postharvest handling and storage causes significant economic damages to the producers [7]. On the other hand, with the increase in public awareness regarding the adverse effects of the use of chemical residues on human health and environmental safety in recent years, there has been a lot of growth in the market for the demand for organic and chemical-free horticultural products [8]. However, products produced for fresh consumption are highly susceptible to major mechanisms of losses, including, enzymatic bleaching, water loss, and microbial contamination [9].

To increase the postharvest shelf life of harvested fruit and vegetables, there are some useful treatments, including modified atmosphere storage, changed atmosphere packaging, edible coatings, and the use of different natural compounds [10]. Among the treatments mentioned, the use of edible coatings is one of the promising methods for preventing water loss, decreasing metabolic and enzymatic activities and maintaining the aroma and flavor of the crops; because of a relative permeability to different respiratory gases, these coatings prevent the adverse effects of common modified atmosphere storages and packages, such as creating an unpleasant odor and smells [7].

Edible coatings are renewable compounds, including lipids, polysaccharides, and proteins, which are responsible for decreasing the exchange of water vapor, gases, etc., and many compounds used in postharvest technologies such as antimicrobial agents, antioxidants, dyes, and authorized food additives can also be added to them [11]. In addition, a new approach for enhancing fruit phytochemicals, quality attributes, and postharvest life is the use of natural compounds, such as plant growth regulators (PGR) and phytohormones as alternatives to chemical treatments during the production and postharvest stages of food crops [12,13].

Chitosan is a polymer of $(4,1) \beta-\mathrm{N}$-acetyl-d-glucosamine derived from the chitin of crustaceans, insects, and fungi, which can play an important role in the physiology of plants and harvested crops [14]. It can be used as an edible coating for many harvested horticultural products [15]. In addition to having semi-permeability behavior against respiratory gases, resulting in decreased respiration and metabolic activities, chitosan has direct antimicrobial, bactericidal, and antivirus properties that reduce the need for the use of chemical compounds and increase the safety of the food products $[15,16]$. Due to its semi-permeability, chitosan has a relative permeability to water vapor and is a good inhibitor of oxygen exchange, thereby altering the internal atmosphere of the product and increasing the shelf life of the product $[16,17]$. As a PGR, chitosan has been shown to enhance the natural resistance mechanisms of the plants and harvested crops against different pathogens and stress conditions [18].

Moreover, the use of nanotechnology in edible coatings and packaging can increase their efficiency compared to conventional edible coatings and improve the quality of edible coatings by reducing the particle size and the pores of the coatings [19]. The small size of nanoemulsion particles has two important effects-(1) it increases the stability and physicochemical properties of the coating and (2) it can increase the biological activity of lipophilic materials by increasing the surface area to the mass unit rate [20]. Nanoemulsions enhance the bioavailability of bioactive materials [21] and the bactericidal properties of antimicrobials because they can pass as active elements across the bio-membranes [22] Nanoemulsions are now widely used to cover, protect, and transfer lipophilic materials on foods, fruit, and vegetables [23,24].

Raspberry are rich sources of different powerful antioxidants including anthocyanins, ellagic acid, gallic acid, catechins, camphor, and salicylic acid, with high capacity in the prevention of unwanted damages of free radicals and reactive oxygen species (ROS) to cell membranes and other structures in the human body. Previously mentioned antioxidant compounds may reduce a person's risk of heart disease by preventing platelet buildup and lowering blood pressure by anti-inflammatory agents. Rubus antioxidant compounds and anti-inflammatory agents are correlated with cancer protection by reducing the reproduction of cancer tumors. Due to the high levels of antioxidant compounds such as 
vitamin $C$ and polyphenols, raspberries have an oxygen-radical absorbance capacity of about $30 \mathrm{mM}$ to $100 \mathrm{mM}$ per $100 \mathrm{gr}$ [25]. Ascorbic acid or vitamin C provides extracellular and intracellular antioxidant activity mainly by scavenging reactive oxygen species [26].

Raspberries are also a great source of riboflavin, folate, niacin, magnesium, potassium, and copper. The presence of these nutrients and their synergistic role in improving human health have led to the fact that this fruit is a good source to answer daily needs for various micronutrients (anthocyanins, polyphenols, ascorbic acid, fiber, proteins, vitamins, and minerals) [27]. This fruit is one of the most popular berry fruit, but due to very high sensitivity to different postharvest losses, such as rapid water loss, mechanical damage, and pathogen sensitivity, they have a very short shelf life, leading to rapid phytochemical depletion and quality deterioration [28].

The purpose of this research was to increase the shelf life and maintain phytochemical contents and quality of this valuable fruit with the use of chitosan nanoparticle coatings as a natural safe compound. We studied the effects of this coating at different concentrations on decay extension rate, weight loss, different quality parameters of the fruit, and different resistance mechanisms, including total antioxidant activity and different antioxidant fractions. Moreover, the effects of this coating on fruit taste and flavor as important factors determining consumer acceptance were studied.

\section{Materials and Methods}

\subsection{Preparation of the Fruit for the Treatment}

Raspberry fruit (Rubus sanctus Schreber) were collected in August at commercial maturity from Khan Valley, Urmia, with a longitude of $45^{\circ} 07^{\prime} 09^{\prime \prime}$, the latitude of $37^{\circ} 19^{\prime} 16^{\prime \prime}$ and an elevation above sea level of $1392 \mathrm{~m}$. Raspberry shrubs were wild-growing and organic. Sampling was carried out early in the morning. The fruit was selected for the similarity of size, maturity, and color, and the damaged and unshaped fruit samples were removed. The samples were then transferred in a fridge of $4 \pm 1^{\circ} \mathrm{C}$ to the Department of Horticulture Science of Faculty of Agriculture of Urmia University (Urmia, Iran). The Rubus sanctus Schreber species identification was conducted by botanist Dr. Shahram Bahadori. The voucher herbarium samples of the collected Rubus sanctus Schreber species have been deposited at the herbarium of Urmia University of Medical Sciences (HUPS-359). For each experimental unit, $5 \mathrm{~g}$ of fruit was used. Preliminary measurements of the indices of the fruit were carried out on harvest day (day 0 ) and the fruit was treated with different emulsions containing nanoparticles of chitosan (ECNPC) on the same day of harvest.

\subsection{Preparation of Chitosan Nanoemulsion}

Chitosan (degree of acetylation (85\%), molecular weight (50,000-80,000 Da), and size of nano chitosan particles: $<50 \mathrm{~nm}$ ) nanoemulsion was purchased from Nano Novin Polymer Co. (Sari, Iran). Before applying the treatment, to ensure the quality of the edible coating, the coating was sent to Shahid Beheshti University (Tehran, Iran) to determine the particle size. The dynamic light scattering (DLS) device (NanoPhox 90-246 V, Sympatec $\mathrm{GmbH}$, Clausthal-Zellerfeld, Germany) was used to determine the size of nanoemulsion particles. The type of device lamp was He-Ne Laser $623 \mathrm{~nm}$, and the range of measurement of this device was $1-10,000 \mathrm{~nm}$.

\subsection{Application of the Nanoemulsion in Raspberry}

For the treatment of the fruit with chitosan nanoemulsion, concentrations of $0,2.5$, and $5 \mathrm{~g} \mathrm{~L}^{-1}$ were prepared. The fruit ( $60 \mathrm{~g}$ of fruit for each repetition) were immersed in containers containing chitosan nanoemulsion for three minutes, and after drying for 8-10 min placed in the pre-sterilized disposable plastic containers (polyethylene terephthalate; $23 \mathrm{~cm} \times 17 \mathrm{~cm} \times 8.5 \mathrm{~cm}$ ) with four vent holes in the sides ( $2 \mathrm{~mm}$ in diameter). The lid of the containers (clamshell package) was sealed with parafilm to prevent the exchange of air and the packages were stored at cold storage of $4 \pm 1{ }^{\circ} \mathrm{C}$ with relative humidity (RH) of $85-95 \%$ for $9 \mathrm{~d}$ (Figure 1). 
Control
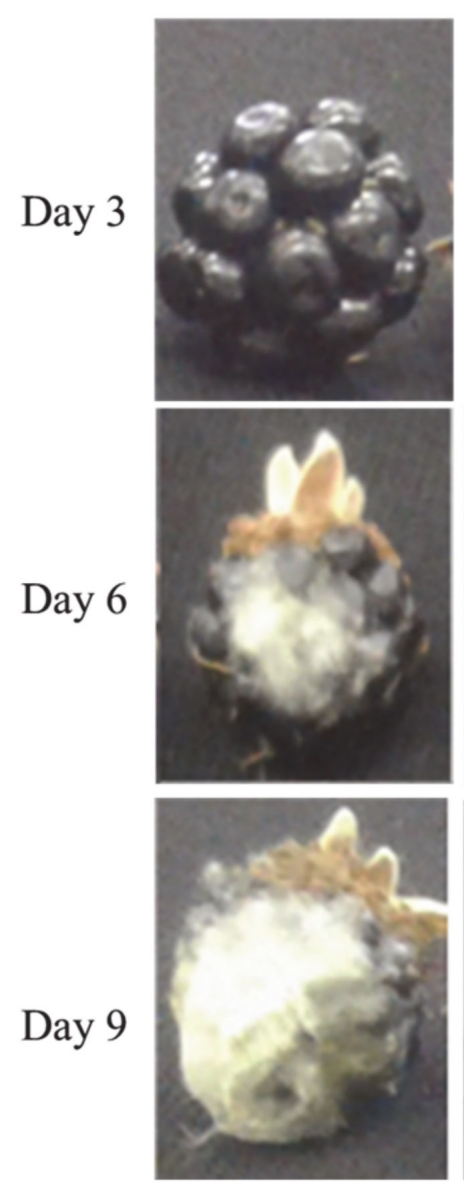

$2.5 \mathrm{~g} / \mathrm{L}$
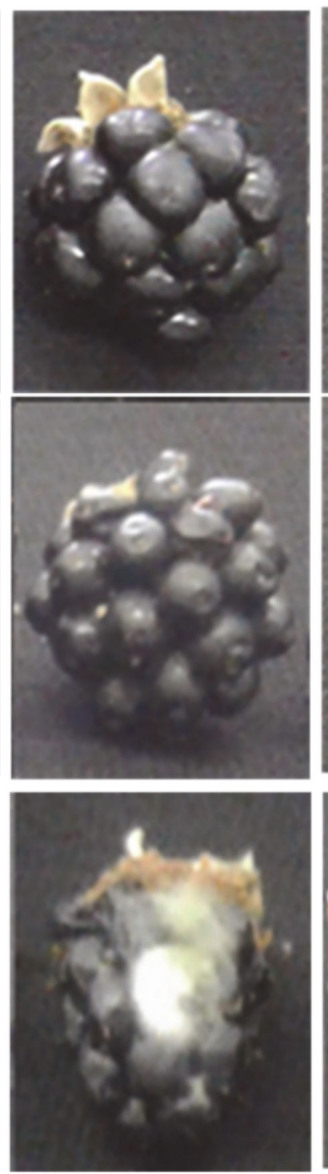

$5 \mathrm{~g} / \mathrm{L}$
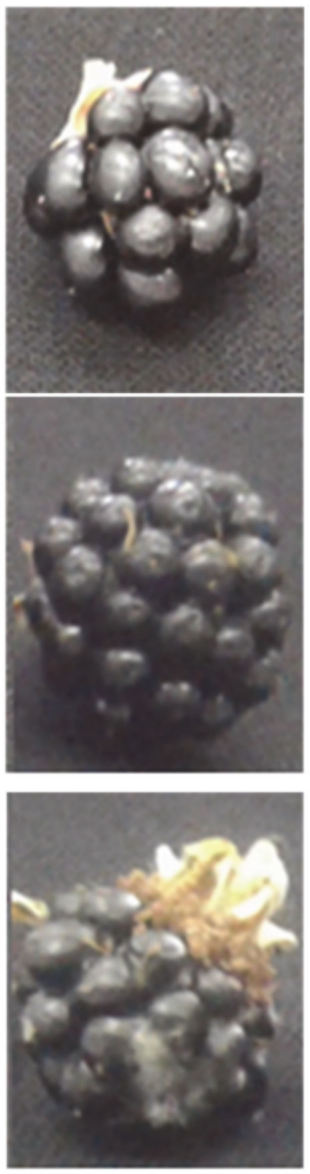

Figure 1. Effect of chitosan nanoemulsion on the shelf life of raspberry.

\subsection{Quality Evaluation}

\subsubsection{Fruit Titratable Acidity (TA), Total Soluble Solids (TSS), and $\mathrm{pH}$}

Total acidity was calculated by the titration method using sodium hydroxide $(0.1 \mathrm{~N})$ in terms of citric acid. In other words, it was titrated with soda solution $(0.1 \mathrm{~N})$ to reach $\mathrm{pH}$ 8.3. After applying, the value of the used soda was introduced in the following formula, and the acidity was calculated based on $\mathrm{g}$ of citric acid in $2 \mathrm{~L}$ of fruit extract and then, converted to percent [29]:

$$
\mathrm{TA}=\frac{100 \times \mathrm{M} \times \mathrm{N} \times \mathrm{V}}{\mathrm{S} \times \mathrm{n}}
$$

where TA = acidity value based on $\mathrm{g}$ of citric acid in $2 \mathrm{~L}$ sample extract, $\mathrm{M}=$ molecular weight of the dominant acid, $\mathrm{n}=$ dominant acid capacity, $\mathrm{V}=$ volume of the used soda, $\mathrm{S}=$ amount of the extract used, and $\mathrm{N}=$ normality of the used soda.

TSS of the sample extract was measured by a manual refractometer (ATAGO, Tokyo, Japan) at laboratory temperature. The distilled water was used to be calibrated the refractometer. A pH meter (pH-Meter CG 824, SCHOTT, Hofheim, Germany) was used to measure the $\mathrm{pH}$ of the fruit juice.

\subsubsection{Weight Loss of the Fruit}

The digital scale (CANDGL300) was used to measure the value of the weight loss of the fruit. For this purpose, the difference in the weight of the fruit was calculated after 
$3 \mathrm{~d}, 6 \mathrm{~d}$, and $9 \mathrm{~d}$ of storage, and the value of the weight loss compared to the first day was obtained [30].

$$
\text { Weight Loss }(\%)=\frac{\text { Primary weight }- \text { sec ondary weight }}{\text { Primary weight }} \times 100
$$

\subsubsection{Fruit Firmness}

A TA-XT plus texture analyzer (Stable Micro Systems Ltd., Godalming, UK) was used to determine the firmness of raspberries. The probe was set at a speed of $2 \mathrm{~mm} / \mathrm{s}$ for test. The value of pressure $(\mathrm{N})$ that was introduced into the tip of the firmness tester due to the resistance of the fruit tissue was read on the device [31].

\subsubsection{Decay Extension Rate and Fruit Sensory Evaluation}

The effect of chitosan nanoemulsion at different concentrations on decay extension rate and consumer acceptance was evaluated by 72 evaluators ( 24 male and 48 females) with prior experience about the sensory attributes of this type of product. Measurement of the decay extension rate was performed by observation, and their average opinions were discussed and recorded. In this regard, score 1 was given to the samples with the lowest decay extension rate and score 10 was given to the highest rate.

The fruit panel test was also conducted for sensory evaluation. A randomized (complete) block design was conducted. The panelists tested the fruit taste and flavor and their average opinions were analyzed. Before each session, panelists were informed about the objectives of the study and the instructions to complete the test. The samples were individually labeled with aleatory numbers and randomly served to panelists situated in individual cabins during the sessions. For increasing the accuracy of sensory analysis between each testing crackers (unsalted) and water were utilized. The scores were ranged from 1 to 10 , i.e., score 1 was given to samples with better taste and score 10 was given to those with the lowest sensory indices. The measurements were performed for the third, sixth, and ninth day separately [30].

\subsection{Measurement of Total Phenolics Content (TPC)}

TPC was determined using Folin-Ciocalteu reagent according to the method of Alirezalu et al. [32]. A total of $30 \mu \mathrm{L}$ concentrated extract was poured into the test tube and $90 \mu \mathrm{L}$ distilled water was added. Then, $600 \mu \mathrm{L}$ of $10 \%$ Folin was added, and after $10 \mathrm{~min}$, $480 \mu \mathrm{L}$ of $7.5 \%$ sodium carbonate was added, and after placing it for $30 \mathrm{~min}$ in the dark at room temperature, a spectrophotometer (UV-1800, Shimatzu Corporation, Kyoto, Japan) was used to read the absorbance at $760 \mathrm{~nm}$. Gallic acid was used as a standard. The total phenol content of extracts was expressed as g of gallic acid equivalent (GAE) per $L$ of the fruit extract.

\subsection{Measurement of Total Flavonoid Content (TFC)}

To measure the total flavonoid content, $50 \mu \mathrm{L}$ of the concentrated extract was poured into the test tube and $150 \mu \mathrm{L}$ of $5 \%$ sodium nitrite was added. After $5 \mathrm{~min}, 300 \mu \mathrm{L}$ of $10 \%$ aluminum chloride was added, and again, after $5-10 \mathrm{~min}, 1000 \mu \mathrm{L}$ of $1 \% \mathrm{NaOH}$ were mixed to the resulting solution and was brought to a volume of $5 \mathrm{~mL}$ with the deionized water and the absorbance of the resulting mixture at $380 \mathrm{~nm}$ was read, compared to the control. Quercetin was used to be drawn the standard curve. The total flavonoid content of the total extracts was expressed as $g$ of quercetin equivalent per $L$ of the fruit extract [33].

\subsection{Total Anthocyanin Content (TAC) Evaluation}

The $\mathrm{pH}$-difference method was used to measure the total anthocyanin content. Firstly, two buffers were prepared with $\mathrm{pH} 1$ and 4 . Then, $2.5 \mathrm{~mL}$ of buffer 1 was poured into the test tube. Afterward, $100 \mu \mathrm{L}$ of the extract was added to the solution poured into the test tube and the absorbance at two wavelengths of $700 \mathrm{~nm}$ and $530 \mathrm{~nm}$ was read. Then, $2.5 \mathrm{~mL}$ of buffer 2 ( $\mathrm{pH} 4.5$ ) was poured into another test tube and $100 \mu \mathrm{L}$ of the 
extract was added, and the absorbance at two wavelengths of $700 \mathrm{~nm}$ and $530 \mathrm{~nm}$ was read. Finally, the following formula was used to be calculated the total absorbance of each of the extracts [34]:

$$
\mathrm{A}=(\mathrm{A} 530-\mathrm{A} 700) \mathrm{pH}=1-(\mathrm{A} 530-\mathrm{A} 700) \mathrm{pH}=4.5
$$

Total anthocyanin content was calculated by g of cyanidin 3-O-glucoside equivalent per kg fresh weight and according to the following formula:

$$
\mathrm{TAC}=\frac{\mathrm{A} \times \mathrm{MW} \times \mathrm{V} \times \mathrm{DF} \times 100}{\varepsilon \times 100}
$$

where $\mathrm{A}=$ Absorbance, $\mathrm{MW}=$ Molecular weight, $\mathrm{DF}=$ Dilution factor, and $\varepsilon=$ Molar absorbance.

\subsection{Measurement of Total Antioxidant Activity}

\section{2,2-Diphenyl-1-Picrylhydrazyl-Hydrate (DPPH) Method}

The 2,2-diphenyl-1-picrylhydrazyl-hydrate (DPPH) method was used to be evaluated the antioxidant activity. For this purpose, $2000 \mu \mathrm{L}$ of the DPPH (pre-prepared) solution was poured into the sterilized test tubes. Then, a specific amount of the fruit extract of each of the samples was added, and the resulting solution was shaken at room temperature and in the dark for $30 \mathrm{~min}$. The value of the absorbance of the resulting solution was read by a spectrophotometer at a wavelength of $517 \mathrm{~nm}$. The above method was also used to be prepared the control, but instead of the extract, $80 \%$ methanol was used and calculated according to the following formula [35]:

$$
\mathrm{RSA}=\frac{(\text { Abs control }) \mathrm{t}=30 \mathrm{~min}-(\text { Abs sample }) \mathrm{t}=30 \mathrm{~min}}{(\text { Abs control }) \mathrm{t}=30 \mathrm{~min}} \times 100
$$

Ferric Reducing Antioxidant Power (FRAP) Method

In measuring the total antioxidant activity by the Ferric reducing antioxidant power (FRAP) method, $50 \mu \mathrm{L}$ of the concentrated extract of raspberry fruit and $3 \mathrm{~mL}$ of fresh FRAP reagent ( $300 \mathrm{mM}$ sodium acetate buffer with the acidity of 3.6, ferric-tris pyridyl-s-triazine 3 , and ferric chloride) were mixed, and the resulting mixture was placed in a warm water bath $\left(37^{\circ} \mathrm{C}\right)$ for $30 \mathrm{~min}$, and the value of the absorbance was read by a spectrophotometer at $593 \mathrm{~nm}$, compared to the control. Iron sulfate was used to be drawn the standard curve and the results of the data were expressed as $\mathrm{mol} \mathrm{Fe}^{+2} / \mathrm{L}$ extract [36].

\subsection{Evaluation of Enzymes Activity}

Phenylalanine Ammonia-Lyase (PAL) Enzyme

The method of Karthikeyan et al. [37] was used under slight modifications to measure the activity of the phenylalanine ammonia-lyase (PAL) enzyme. For this purpose, $0.5 \mathrm{~g}$ of fresh fruit texture was squeezed by using $1.5 \mathrm{~mL}$ extraction buffer $(0.1 \mathrm{M}$ borate buffer, $0.1 \%$ polyvinylpyrrolidone, and $1.4 \mathrm{mM}$ mercaptoethanol) at $\mathrm{pH} 7$. It was then centrifuged at $12{ }^{\circ} \mathrm{C}$ for $15 \mathrm{~min}$ at $12,000 \times \mathrm{g}$. After completion of the centrifuge, the supernatant was used to measure by the enzyme. To measure the enzyme, sample contents contained $30 \mu \mathrm{L}$ of the enzymatic extract, $1 \mathrm{~mL}$ assay buffer $(0.1 \mathrm{M}$ borate buffer, $0.1 \%$ polyvinylpyrrolidone, and $1.4 \mathrm{mM}$ mercaptoethanol) at $\mathrm{pH} 8.8$, and $1 \mathrm{~mL}$ L-phenylalanine $(12 \mathrm{mM})$, were placed in a warm water bath (Benmari method, $30{ }^{\circ} \mathrm{C}$ ) for $30 \mathrm{~min}$, and the absorbance was read by a spectrophotometer at $290 \mathrm{~nm}$. The measurement of the PAL enzyme activity was performed by the Beer-Lambert law with an extinction coefficient of $96301 . \mathrm{cm}-\mu$ in $\mu \mathrm{mol} / \mathrm{min}$ trans-cinnamic acid.

\section{Guaiacol Peroxidase (G-POD) Enzyme Activity}

To measure the activity of the guaiacol peroxidase (G-POD) enzyme; $0.1 \mathrm{~g}$ of the fresh fruit texture was weighed and placed in a Chinese mortar on ice. Then, $1.5 \mathrm{~mL}$ of 
extraction buffer ( $125 \mathrm{mM}$ potassium phosphate buffer) at $\mathrm{pH} 7.8$ was added, and after grinding, the supernatant was poured into a micro-tube and centrifuged at $4{ }^{\circ} \mathrm{C}$ for $10 \mathrm{~min}$ at $15,000 \times g$. To measure the activity of the enzyme, $200 \mu \mathrm{L}$ of the enzymatic extract was poured into the test tube, and $200 \mu \mathrm{L}$ of $22 \mathrm{mM}$ guaiacol was added. Afterward, $2 \mathrm{~mL}$ of $1250 \mathrm{mM}$ potassium phosphate buffer was added. Then, for reading, the above solution was poured into a cell, and to prevent the rapid reaction of hydrogen peroxide with the present solution, hydrogen peroxide was added to a spectrophotometer and the absorbance was read at $0 \mathrm{~min}$ and $1 \mathrm{~min}$ after the addition of hydrogen peroxide at $470 \mathrm{~nm}$, and its unit was expressed as $\mu \mathrm{mol} \mathrm{H}_{2} \mathrm{O}_{2} \cdot \mathrm{min}^{-1}$. $\mathrm{mL}^{-1}$ extract [38].

\subsection{Statistical Analysis}

The experiment was conducted as a completely randomized design with 3 (ECNPC levels) $\times 3$ (storage times) $\times 4$ replications. The data analysis was performed using the SAS software (SAS Institute Inc., Cary, NC, USA). Duncan's multiple range test was used for the comparison of the mean data. The Friedman test based on a completely randomized block design was also used for the analysis of the decay and taste data.

\section{Results}

\subsection{The Coating Structure of Chitosan Nanoemulsion}

In Figure 2, the interval of the particle size of nanoemulsion chitosan is shown by the DLS device. The results of this analysis indicated that most chitosan nanoemulsion particles had a size ranging from $15 \mathrm{~nm}$ to $150 \mathrm{~nm}$. This particle size range is approximately close to the size range of chitosan nanoemulsion particles reported in previous studies $[19,39]$.

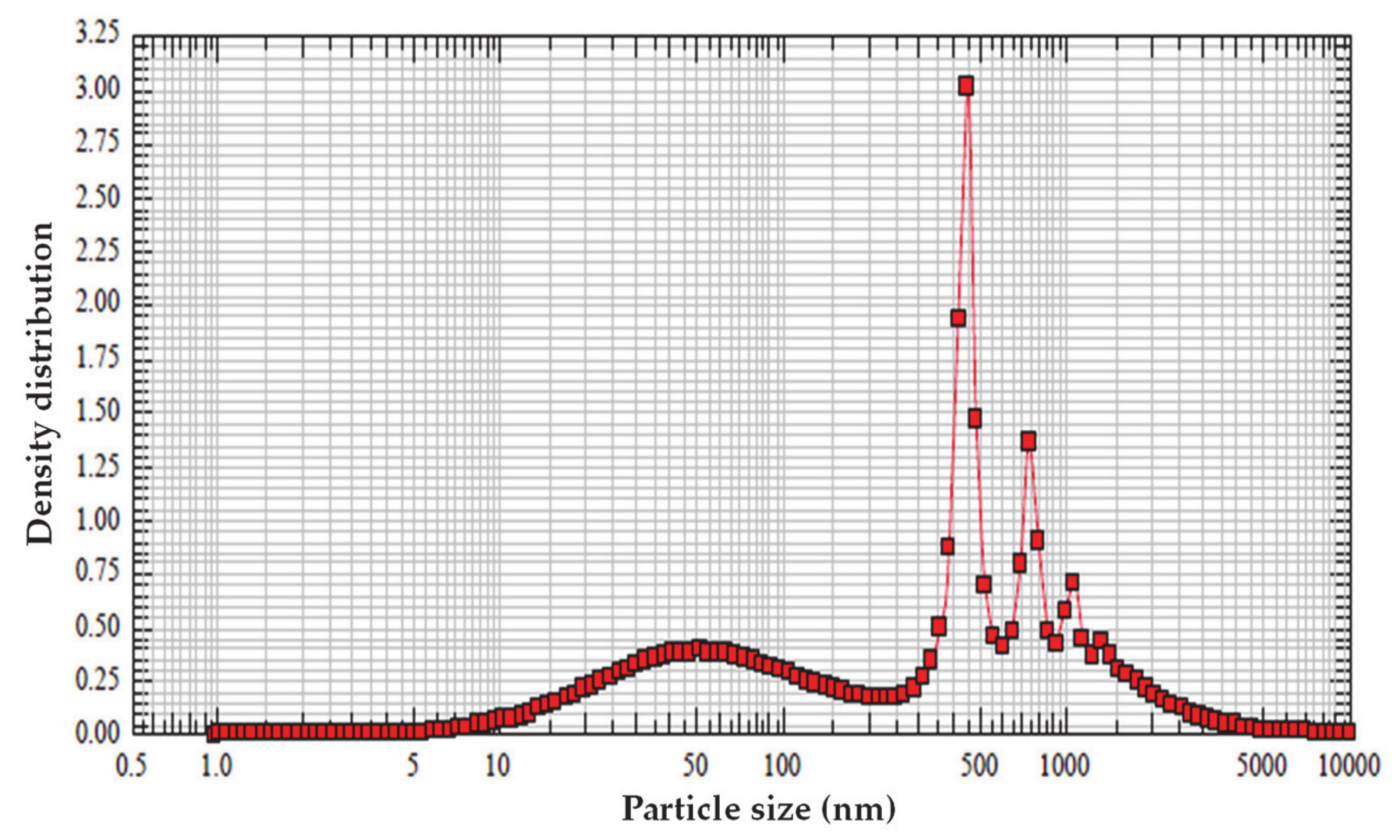

Figure 2. Particle size obtained by dynamic light scattering (DLS) analysis based on size and intensity of emulsion containing nanoparticles of chitosan (ECNPC).

\subsection{TA, TSS, and $p H$}

Fruit TA decreased during storage. TSS content showed an increasing trend during storage, and ECNPC significantly decreased the rate of increase in fruit TSS during storage (Table 1). The highest TA $(1.25 \%)$ was recorded after $6 \mathrm{~d}$ in fruit treated with ECNPC at $5 \mathrm{~g} \mathrm{~L}^{-1}$, and the lowest $(0.90 \%)$ value was recorded in control fruit after $9 \mathrm{~d}$ of cold storage. In both storage periods, the highest TA was seen in fruit treated with $5 \mathrm{~g} \mathrm{~L}^{-1}$ ECNPC $(p<0.01)$. Moreover, the rate of soluble solids varied between $17.33 \%$ to $12.18 \%$, which 
the highest amount was observed in control on the $9 \mathrm{~d}$ after storage, and the lowest was observed after $3 \mathrm{~d}$ in samples treated with a concentration of $2.5 \mathrm{~g} \mathrm{~L}^{-1}$ ECNPC $(p<0.01)$.

Table 1. Effect of different chitosan nano-emulsion treatment on the quality attributes of raspberry at harvest and in storage time at $4 \pm 1{ }^{\circ} \mathrm{C}$.

\begin{tabular}{ccccc}
\hline Days & ECNPC $\left.\mathbf{~ ( ~ L ~ L ~}^{-1}\right)$ & TA (\%) & TSS (\%) & pH \\
\hline 0 & Harvest day & $1.31 \pm 0.01$ & $12.06 \pm 0.02$ & $3.23 \pm 0.03$ \\
3 & 0 & $1.16 \pm 0.03^{\mathrm{ab}}$ & $13.03 \pm 0.37^{\mathrm{e}}$ & $3.96 \pm 0.18^{\mathrm{ab}}$ \\
6 & 0 & $1.04 \pm 0.11^{\mathrm{abc}}$ & $16.10 \pm 0.40^{\mathrm{de}}$ & $3.91 \pm 0.06^{\mathrm{ab}}$ \\
9 & 0 & $0.90 \pm 0.06^{\mathrm{c}}$ & $17.33 \pm 0.30^{\mathrm{a}}$ & $4.05 \pm 0.02^{\mathrm{a}}$ \\
3 & 2.5 & $1.19 \pm 0.09^{\mathrm{ab}}$ & $12.66 \pm 0.25^{\mathrm{de}}$ & $3.84 \pm 0.07^{\mathrm{ab}}$ \\
6 & 2.5 & $1.08 \pm 0.05^{\mathrm{abc}}$ & $14.96 \pm 0.15^{\mathrm{b}}$ & $3.88 \pm 0.03^{\mathrm{ab}}$ \\
9 & 2.5 & $0.98 \pm 0.03^{\mathrm{bc}}$ & $13.58 \pm 0.40^{\mathrm{d}}$ & $3.96 \pm 0.06^{\mathrm{ab}}$ \\
3 & 5 & $1.24 \pm 0.04^{\mathrm{a}}$ & $12.18 \pm 0.29^{\mathrm{e}}$ & $3.02 \pm 0.09^{\mathrm{c}}$ \\
6 & 5 & $1.25 \pm 0.06^{\mathrm{a}}$ & $13.01 \pm 0.04^{\mathrm{c}}$ & $3.84 \pm 0.05^{\mathrm{ab}}$ \\
9 & 5 & $1.02 \pm 0.04^{\mathrm{bc}}$ & $12.96 \pm 0.02^{\mathrm{de}}$ & $3.77 \pm 0.04^{\mathrm{b}}$ \\
\hline & & $* *$ & $* *$ & $* *$
\end{tabular}

$\overline{\mathrm{a}-\mathrm{e}}$ Mean values with different letters indicate significant differences among samples. Data obtained from four replications, mean \pm standard error, ${ }^{* *}$ is significant at the $1 \%$ (Duncan's multiple range test).

ECNPC at both concentrations reduced the fruit $\mathrm{pH}$ compared to the control fruit so that the highest $\mathrm{pH}$ was observed in control fruit in all storage times, and the lowest was observed in treated fruit. With an increase in ECNPC concentration, the effects on decreasing the $\mathrm{pH}$ were increased $(p<0.01)$ (Table 1$)$.

\subsection{Weight Loss}

ECNPC significantly affected fruit weight loss during cold storage (Table 2) $(p<0.01)$. The percentage of weight loss was enhanced in all treatments in storage time, and it was lower in samples treated with ECNPC. With an increase in ECNPC concentration, its effects on retaining fruit weight were increased.

Table 2. Effect of different chitosan nano-emulsion treatments on the quality attributes of raspberry at harvest and in storage time at $4 \pm 1{ }^{\circ} \mathrm{C}$.

\begin{tabular}{cccccc}
\hline Days & $\begin{array}{c}\text { ECNPC } \\
\left(\mathbf{g ~ L}^{-1} \mathbf{)}\right.\end{array}$ & $\begin{array}{c}\text { Loss Weight } \\
\mathbf{( \% )}\end{array}$ & Firmness (N) & Decay & Panel Test \\
\hline 0 & Harvest day & $0.00 \pm 0.00$ & $0.17 \pm 0.00$ & $1.00 \pm 0.00$ & $1.00 \pm 0.00$ \\
3 & 0 & $0.14 \pm 0.00^{\mathrm{d}}$ & $0.13 \pm 0.01^{\mathrm{bc}}$ & $4.90 \pm 0.04^{\mathrm{e}}$ & $4.06 \pm 0.08^{\mathrm{e}}$ \\
6 & 0 & $0.21 \pm 0.01^{\mathrm{bc}}$ & $0.13 \pm 0.01^{\mathrm{bc}}$ & $6.36 \pm 0.06^{\mathrm{d}}$ & $6.85 \pm 0.06^{\mathrm{c}}$ \\
9 & 0 & $0.26 \pm 0.01^{\mathrm{a}}$ & $0.12 \pm 0.00^{\mathrm{bc}}$ & $9.56 \pm 0.02^{\mathrm{a}}$ & $9.00 \pm 0.00^{\mathrm{a}}$ \\
3 & 2.5 & $0.13 \pm 0.00^{\mathrm{de}}$ & $0.23 \pm 0.01^{\mathrm{a}}$ & $2.46 \pm 0.02^{\mathrm{g}}$ & $3.88 \pm 0.03^{\text {ef }^{\mathrm{b}}}$ \\
6 & 2.5 & $0.19 \pm 0.00^{\mathrm{c}}$ & $0.23 \pm 0.01^{\mathrm{a}}$ & $4.83 \pm 0.02^{\mathrm{e}}$ & $7.55 \pm 0.53^{\mathrm{bc}}$ \\
9 & 2.5 & $0.26 \pm 0.01^{\mathrm{a}}$ & $0.16 \pm 0.01^{\mathrm{b}}$ & $8.38 \pm 0.01^{\mathrm{b}}$ & $8.58 \pm 0.03^{\mathrm{a}}$ \\
3 & 5 & $0.12 \pm 0.00^{\mathrm{de}}$ & $0.14 \pm 0.01^{\mathrm{b}}$ & $1.33 \pm 0.02^{\mathrm{h}}$ & $3.20 \pm 0.21^{\mathrm{f}}$ \\
6 & 5 & $0.11 \pm 0.00^{\mathrm{e}}$ & $0.14 \pm 0.02^{\mathrm{b}}$ & $3.56 \pm 0.02^{\mathrm{f}}$ & $4.96 \pm 0.02^{\mathrm{e}}$ \\
9 & 5 & $0.23 \pm 0.01^{\mathrm{b}}$ & $0.09 \pm 0.01^{\mathrm{c}}$ & $7.86 \pm 0.02^{\mathrm{c}}$ & $8.16 \pm 0.01^{\mathrm{ab}}$ \\
\hline
\end{tabular}

$\overline{\mathrm{a}-\mathrm{f}}$ Mean values with different letters indicate significant differences among samples. Data obtained from four replications, mean \pm standard error, ${ }^{* *}$ is significant at the $1 \%$ (Duncan's multiple range test). Chi ${ }_{\text {Decay }}^{2}=31.93$ and $\mathrm{Chi}_{\text {Panel test }}^{2}=31.20$.

\subsection{Firmness}

There was a significant difference between treatments and control fruit $(p<0.01)$. The highest firmness value was observed after $3 \mathrm{~d}$ of storage in fruit treated with $2.5 \mathrm{~g} \mathrm{~L}^{-1}$ ECNPC (Table 2). 


\subsection{Decay Extension and Fruit Taste}

A statistically significant difference was recorded between the fruit treated with different levels of ECNPC and the control fruit at all evaluation times (Table 2) $(p<0.01$ ). The results show that the rate of decay extension in all treatments was high during storage, and the chitosan nanoemulsion treatments reduced the rate of this increasing trend. With the increase in ECNPC concentration the effects on decreasing decay extension rate were increased $(p<0.01)$ (Table 2).

The coating, in a concentration-dependent manner, significantly retained fruit taste and flavor quality $(p<0.01)$ (Table 2). The taste value of the samples varied between 3.2 and 9 , which the highest value was related to the control sample after $9 \mathrm{~d}$ of storage indicating the lowest taste and flavor rate. On the contrary, the highest taste and flavor rate was observed in $5 \mathrm{~g} \mathrm{~L}^{-1}$ chitosan nanoemulsion coating after $3 \mathrm{~d}$ of storage (Table 2).

\subsection{Total Phenol Content}

Fruit total phenol content was significantly affected by the treatment $5 \mathrm{~g} \mathrm{~L}^{-1}$ chitosan nanoemulsion, and the treated fruit showed the highest phenolics at all evaluation times (Figure 3a) $(p<0.01)$. After $9 \mathrm{~d}$ of storage, the highest content of total phenol $\left(57.53 \mathrm{~g} \mathrm{~L}^{-1}\right)$ was related to the samples treated with $5 \mathrm{~g} \mathrm{~L}^{-1}$ chitosan nanoemulsion, and the lowest rate ( $\left.26.78 \mathrm{~g} \mathrm{~L}^{-1}\right)$ was related to the samples treated with $2.5 \mathrm{~g} \mathrm{~L}^{-1}$ chitosan nanoemulsion after $3 \mathrm{~d}$ of storage (Figure $3 \mathrm{a}$ ).

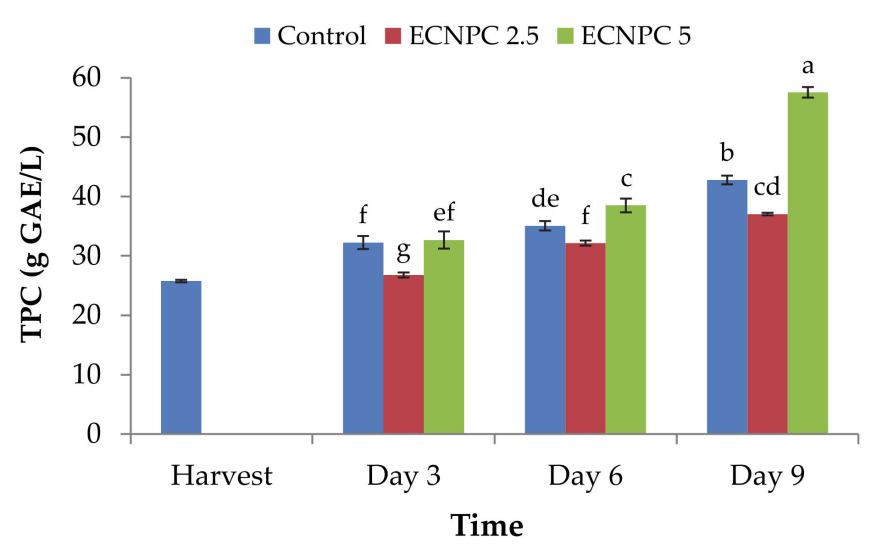

(a)

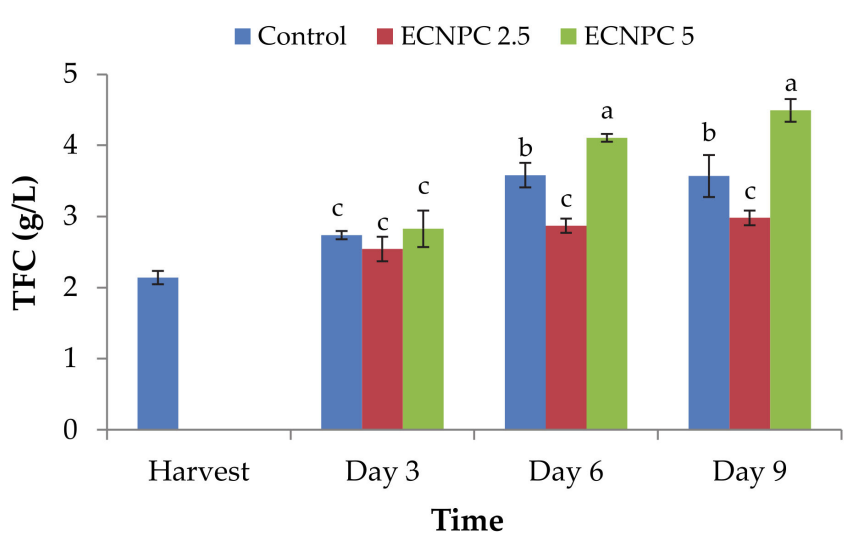

(b)

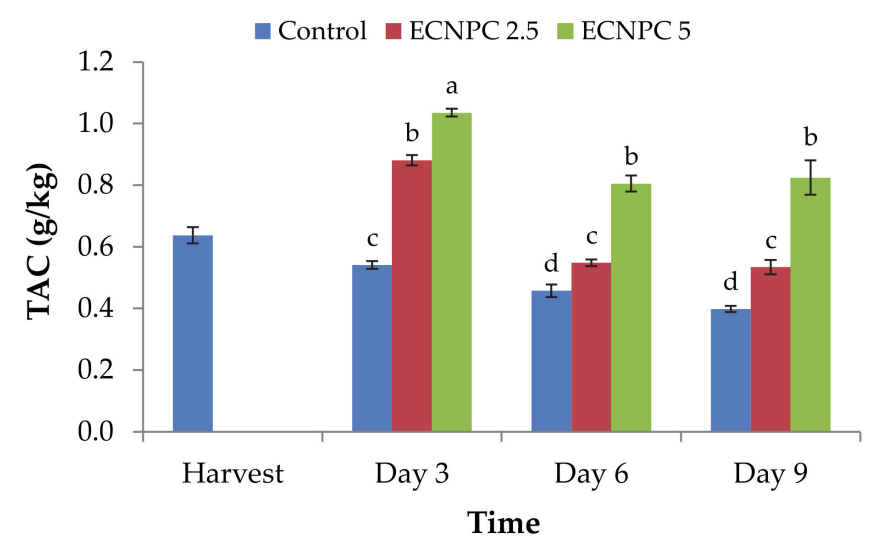

(c)

Figure 3. Effect of chitosan nano-emulsion coatings treatment (at $0 \mathrm{~g} \mathrm{~L}^{-1}, 2.5 \mathrm{~g} \mathrm{~L}^{-1}$, and $5 \mathrm{~g} \mathrm{~L}^{-1}$ ) on (a) total phenolics content, (b) total flavonoid content, and (c) total anthocyanin content of raspberries stored for $9 \mathrm{~d}$ (at $4 \pm 1{ }^{\circ} \mathrm{C}$ with $90-95 \%$ $\mathrm{RH})$. Control refers to untreated raspberries. The data shown are the mean \pm standard error of four replicates. Different letters indicate statistical significance $(p<0.01)$. 


\subsection{Total Flavonoid Content}

The total flavonoid content of all fruit in all treated and control samples showed an increasing trend during storage. At all evaluation times, the highest total flavonoid content was recorded in fruit treated with ECNPC at $5 \mathrm{~g} \mathrm{~L}^{-1}$, but the increase in flavonoid content of fruit treated with $2.5 \mathrm{~g} \mathrm{~L}^{-1}$ was not significant (Figure 3b).

\subsection{Total Anthocyanin Content}

At all evaluation times, the samples treated with chitosan nanoemulsion had more anthocyanin content than the control samples, and among the treatments, $5 \mathrm{~g} \mathrm{~L}^{-1}$ chitosan nanoemulsion was more effective than $2.5 \mathrm{~g} \mathrm{~L}^{-1}$ in enhancing the anthocyanin content of the fruit. The amount of this parameter varied from $1.0355 \mathrm{~g} / \mathrm{kg}$ in the samples treated with $5 \mathrm{~g} \mathrm{~L}^{-1}$ chitosan nanoemulsion on the third day after storage to $0.3985 \mathrm{~g} / \mathrm{kg}$ on the ninth day in the control samples $(p<0.01)$ (Figure 3c).

\subsection{Antioxidant Activity}

3.9.1. DPPH Method

Changes in antioxidant capacity in the raspberry fruit treated with chitosan nanoemulsion are shown in Figure 4a. According to the results, this index showed an increasing trend in all treatments during storage so that the highest content $(85.16 \%)$ was related to the fruit treated with $5 \mathrm{~g} \mathrm{~L}^{-1}$ chitosan nanoemulsion after $9 \mathrm{~d}$ of storage, while the lowest (56.41\%) was observed in fruit treated with the same concentration of chitosan nanoemulsion after $3 \mathrm{~d}$ of storage. Meanwhile, there was a statistically significant difference between the treated and control samples $(p<0.01)$.

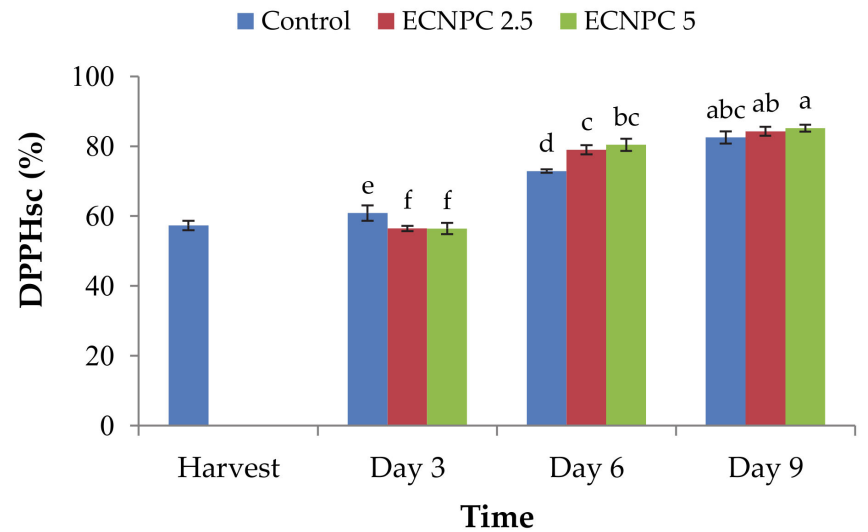

(a)

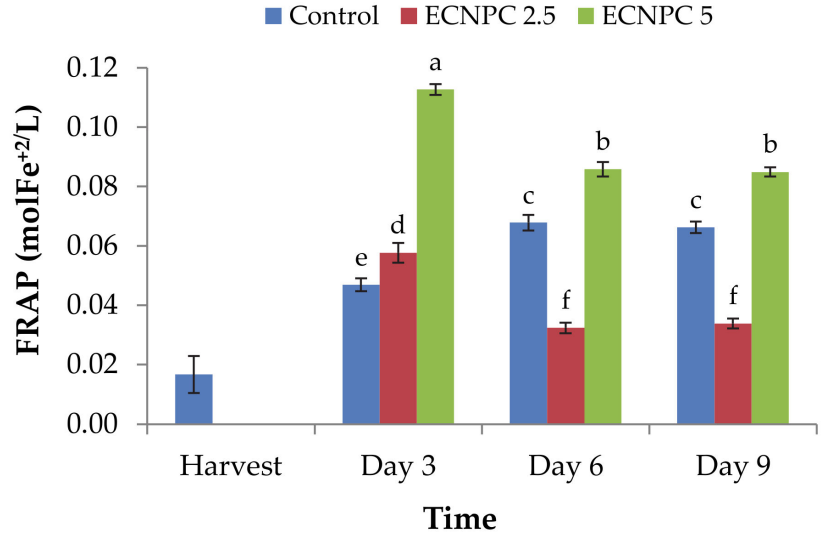

(b)

Figure 4. Effect of chitosan nano-emulsion coatings (at $0 \mathrm{~g} \mathrm{~L}^{-1}, 2.5 \mathrm{~g} \mathrm{~L}^{-1}$, and $5 \mathrm{~g} \mathrm{~L}^{-1}$ ) on antioxidant activity (a) 2,2diphenyl-1-picrylhydrazyl-hydrate (DPPH) and (b) Ferric reducing antioxidant power (FRAP) of raspberries stored for $9 \mathrm{~d}$ (at $4 \pm 1{ }^{\circ} \mathrm{C}$ with $90-95 \% \mathrm{RH}$ ). Control refers to untreated raspberries. The data shown are the mean \pm standard error of four replicates. Different letters indicate statistical significance $(p<0.01)$.

\subsubsection{FRAP Method}

The results of the analysis of variance of the antioxidant activity data using the FRAP method showed that there was a statistically significant difference between the samples treated with chitosan nanoemulsion and the control samples at a $1 \%$ level. In other words, there was a significant difference between chitosan nanoemulsion levels and the control samples $(p<0.01)$. However, there was no statistically significant difference between the sixth and the ninth day in any of the treatments (chitosan nanoemulsion of 2.5 and $5 \mathrm{~g} \mathrm{~L}^{-1}$ and the control). Furthermore, the antioxidant activity level varied from $0.11275 \mathrm{~mol} / \mathrm{L}$ to $0.03238 \mathrm{~mol} / \mathrm{L}$ (Figure 4b). 


\subsection{Anti-Stress and Antioxidant Enzymes Activity \\ 3.10.1. PAL Enzyme Activity}

PAL enzyme activity in all treatments, except for the $2.5 \mathrm{~g} \mathrm{~L}^{-1}$ treatment with chitosan nanoemulsion on the third day, showed an increasing trend in different during storage $(p<0.01)$. Moreover, the highest enzyme activity $(118.88 \mu \mathrm{mol} / \mathrm{min}$ trans-cinnamic acid $)$ among the samples was related to the treatment of $5 \mathrm{~g} \mathrm{~L}^{-1}$ chitosan nanoemulsion in the ninth day after storage, and the lowest $(49.52 \mu \mathrm{mol} / \mathrm{min}$ trans-cinnamic acid) was observed for the treatment of $2.5 \mathrm{~g} \mathrm{~L}^{-1}$ chitosan nanoemulsion on the third day after storage (Figure 5a).

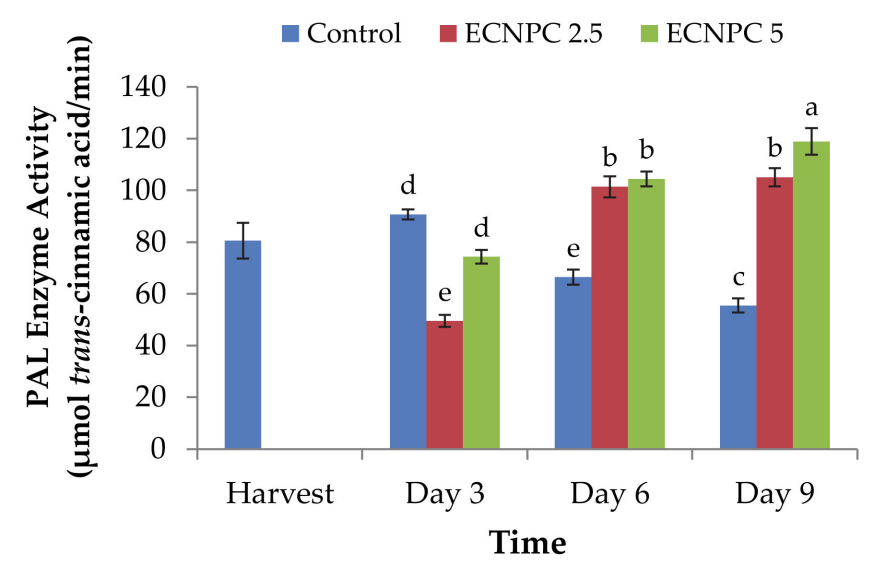

(a)

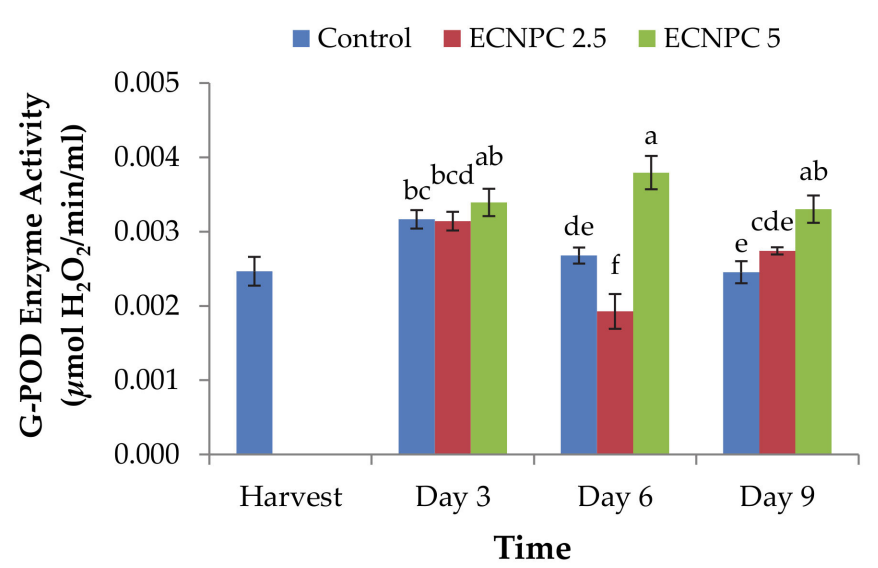

(b)

Figure 5. Effect of chitosan nano-emulsion coatings (at $0 \mathrm{~g} \mathrm{~L}^{-1}, 2.5 \mathrm{~g} \mathrm{~L}^{-1}$, and $5 \mathrm{~g} \mathrm{~L}^{-1}$ ) on antioxidant activity: (a) phenylalanine ammonia-lyase (PAL) enzyme activity and (b) guaiacol peroxidase (G-POD) enzyme activity of raspberries stored for $9 \mathrm{~d}$ (at $4 \pm 1{ }^{\circ} \mathrm{C}$ with $90-95 \% \mathrm{RH}$ ). Control refers to untreated raspberries. The data shown are the mean \pm standard error of four replicates. Different letters indicate statistical significance $(p<0.01)$.

\subsubsection{G-POD Enzyme Activity}

G-POD enzyme activity varied from $0.001 \mu \mathrm{mol} \mathrm{H}_{2} \mathrm{O}_{2} \cdot \mathrm{min}^{-1} \cdot \mathrm{mL}^{-1}$ extract to $0.003 \mu \mathrm{mol}$ $\mathrm{H}_{2} \mathrm{O}_{2} \cdot \mathrm{min}^{-1} \cdot \mathrm{mL}^{-1}$ extract $(p<0.01)$ in different treatments and during storage. According to Figure $4 \mathrm{~b}$, treatment of fruit with $5 \mathrm{~g} \mathrm{~L}^{-1}$ chitosan nanoemulsion was more effective in enhancing the G-POD enzyme activity during storage $(p<0.01)$ (Figure $5 b)$.

\section{Discussion}

Acidity is an important parameter in maintaining fruit quality, which is directly related to the concentration of dominant organic acids in samples [40]. Organic acids are used by the respiration reactions to provide the necessary energy for the normal activities of the cells in storage time [41]. Therefore, the acid content and the $\mathrm{pH}$ of the fruit reflect the status of the fruit from the senescence point of view. According to the results of this study, the total acidity content showed a decreasing trend and the $\mathrm{pH}$ showed an increasing trend over time, which can be due to the consumption of the organic acid in the respiration process and their conversion to sugars [31]. ECNPC, as any other coating, reduces the respiration and ethylene production rates by restricting the gas exchange resulting in elevated $\mathrm{CO}_{2}$ and decreased $\mathrm{O}_{2}$, thereby reducing the consumption of organic acids and preventing an increase in fruit $\mathrm{pH}$ [42].

Change in soluble solids depends on metabolic activities and the activity of different cell wall degrading enzymes. An increase in metabolic activities leads to enhanced ethylene production and a subsequent increase in the activity of degrading enzymes resulting in a dramatic increase in the TSS content of the fruit [43]. Therefore, any decrease in metabolic activities will decrease the ethylene biosynthesis and action resulting in the prevention 
of a dramatic increase in TSS content. By restricting the gas exchange and making a modified atmosphere in the fruit, chitosan coating decreases ethylene production and senescence rate and prevents cell wall degradation processes [44]. The positive effect of the ECNPC in retaining fruit firmness in this study demonstrates the effectiveness of this treatment in decreasing the activity of cell wall degrading enzymes probably by decreasing ethylene production and action. However, the effect of chitosan on soluble solids content is different for different types of fruit; for example, in papaya fruit, the coating did not have a significant effect on soluble solids but increased the soluble solids in mangos [45].

Weight loss of harvested crops is the consequence of water loss and the respiration process. With progress in senescence, the water of the fruit is lost due to transpiration; the weight loss is also related to the consumption of fruit carbohydrates and organic acid reserves. Water loss, in turn, accelerates senescence by enhancing the production of free radicals and ROS [46]. The amount of respiration and the consumption of sugar by the cell lead to more water loss, which is an important factor in the deterioration of the products [13]. Findings demonstrate that these films/coatings act as a barrier on the surface of fruit and vegetables, which causes higher moisture and water retention, creating favorable micro-environments by optimizing the concentration of gases and delaying the ripening process [47]. The role of chitosan-based edible coating is to restrict water vapor exchange between the fruit and the environment, decrease the respiration and metabolic activities, and activate the mechanisms of cuticle formation in the tissues. In fact, as an elicitor, chitosan can activate the PAL and polyphenol oxidase (PPO) enzymes and other enzymes playing roles in the biosynthesis of polyphenols and cuticle [48]. It is well demonstrated by researchers that these additives play an important role in extending the shelf life and maintaining the nutrient profile of numerous fruit and vegetables. These functional molecules play a synergistic role along with the chitosan and alginate-based edible coatings and retain the moisture and antioxidant potential, enhance the activity of antioxidant enzymes, reduce the activity of browning enzymes, and impart antimicrobial properties in fresh fruit and vegetables. All these properties help in sustaining the appearance, lowering the senescence, and extending the life of the coated fruit and vegetables [47]. In this study, the effects of chitosan nanoparticle-containing coating on enhancing PAL, glutathione peroxidase (GPOX), and different antioxidant fractions were demonstrated. Our results show that chitosan-based coating acts as a physical barrier for the gases and water vapor [49] and enhances the anti-stress and antioxidant properties of the fruit.

The role of chitosan nanoparticles in decreasing decay extension is related both to the direct antifungal activity of the chitosan and the activation of different resistance mechanisms and anti-stress systems [50]. The quality of fruit is defined by its characteristics, such as shape, size, color, and lack of defects, including cuts and decay [42]. The appearance of the product is the most important index affecting the marketability and the presence of any signs of contamination and decay and softening of fruit reduces the market demand of the product. The decay organisms can extend and grow on the surface of shrunken, wilted, injured, and softened fruit. Therefore, reducing the senescence and deterioration rate prevents the growth of decay symptoms and maintains the appearance and market demand of the product [51]. Our results indicate that ECNPC can decrease decay extension in raspberries during storage resulting in the safety and postharvest life enhancement. The results of this study showed that with an increase in the concentration of chitosan nanoemulsion, the decay extension rate was better controlled and fruit treated with $5 \mathrm{~g} \mathrm{~L}^{-1}$ chitosan nanoemulsion showed the lowest decays.

Chitosan acts as an active substance at the surface of fungal and bacterial cells, which makes them more permeable [52]. This interaction is mainly assumed to be electrostatic and occurs among the positive loads of chitosan amino acids and negative loads on the cell surface of microorganisms [53]. In general, the permeation of the cell surface causes the leakage of intracellular material and thereby causing cell death [54].

Phenolic compounds, including different polyphenols, flavonoids, and anthocyanins, are powerful antioxidants and antipathogen compounds, and a coating containing chi- 
tosan nanoparticles is able to restrict decay extension directly as a natural fungicide and indirectly as a resistance mediating elicitor [55]. Phenolic compounds are one of the most important secondary metabolites and are chemically very diverse; their biosynthesis is initiated with the phenylalanine, tyrosine, and tryptophan amino acids [56]. Anthocyanins also play the most important role in raspberry fruit color and overall quality. Phenolic compounds of raspberries inhibit liposome oxidation in the body. These compounds also have significantly shown a high capacity to eliminate singlet oxygen (free radical) or act as a hydrogen supplier [57]. The powerful antioxidative and anticancer activities of raspberries phenolic antioxidants in the human body have been well demonstrated [58]. After harvest, the concentrations of phenolic and flavonoids compounds are either substantially fixed or decreased [59]. As a novel and interesting finding, in this study, we found that chitosan nanoemulsion coating substantially enhances the biosynthesis and accumulation of different phenolic contents including total phenolics, flavonoids, and anthocyanin contents of the raspberry fruit during storage, resulting in an enhanced health-promoting capacity of the fruit. Moreover, these compounds, by detoxifying the free radicals and ROS, act as anti-stress and anti-senescence agents in the fruit resulting in enhanced postharvest life and quality maintenance.

PAL plays a key role in different phenolic biosynthesis pathways called the phenylpropanoid pathway [60]. It has been demonstrated that PAL activity decreases during the maturity and postharvest stages [61]. In addition, with the increase in the activity of the PPO activity during the senescence process, the consumption of polyphenols increases, and as a result, the content of total phenolic compounds decreases with the aging of the fruit tissue [62]. The results of this study show that the treatment enhanced the activity of PAL, resulting in the production of different phenolic compounds. On the other hand, edible coatings such as chitosan, by protecting the surface of the products, have been shown to reduce oxygen and thereby reducing the oxidation of phenolics [63].

Guaiacol peroxidase is one of the important antioxidant enzymes that were increased by an edible coating containing nanoparticles of chitosan in this study. This enzyme has been reported to show high activity in biological systems against hydrogen peroxide. Hydrogen peroxide is an important ROS-attacking cell membrane, and the increase in GPOX activity is pivotal for protecting the fruit cell membranes against peroxidation of lipids and DNA hydroperoxides [64].

Different enzymatic antioxidants are the cells' weapons against the oxidation of biological molecules such as lipids, proteins, carbohydrates, and deoxyribonucleic acid by free radicals and ROS $[65,66]$. The free radicals and ROS are produced during normal cell metabolism and attach the biomolecules of the cells called oxidative damage. To prevent oxidative stress, plant cells activate their antioxidant systems and respond to oxidative damage through the activation of different antioxidant systems [67]. Our results indicate that the antioxidant capacity, measured with both DPPH and FRAP methods, increases in the fruit treated with $5 \mathrm{~g} \mathrm{~L}^{-1}$ chitosan nanoemulsion. The use of edible coatings increases the capacity of the fruit antioxidant system and protects the cells against oxidative stress and pathogen attack $[68,69]$.

\section{Conclusions}

In summary, our findings indicate that the use of chitosan nanoparticles can enhance different antioxidant fractions and the total antioxidant activity of raspberry fruit. Chitosan nanoemulsion treatments effectively prevented from the substantial loss in fruit taste and flavor during the storage period, while the control fruit exhibited off-flavors and bad taste. The taste and aroma during storage in the warehouse are significantly reduced due to increased respiration and enzymatic activity of the fruit. In the present study, the fruit treated with chitosan nanoemulsion was generally considered to be better for the sensory quality due to reduced respiration, metabolic activities, decay extension, weight loss and softening, and enhanced phytochemical contents. Competency of edible film/coatings and 
nanoforms in extending the shelf life without affecting the nutritional properties and safety aspects of fruit and vegetables still requires further attention.

Author Contributions: Conceptualization, H.S. and A.A.; writing-original draft preparation, S.R.I. and M.A.; writing—review and editing, H.S., A.A., M.P., and J.M.L. All authors have read and agreed to the published version of the manuscript.

Funding: This research received no external funding.

Institutional Review Board Statement: Not applicable.

Informed Consent Statement: Not applicable.

Data Availability Statement: The data presented in this study are available on request from the corresponding authors.

Conflicts of Interest: The authors declare no conflict of interest.

\section{References}

1. Alirezalu, K.; Pateiro, M.; Yaghoubi, M.; Alirezalu, A.; Peighambardoust, S.H.; Lorenzo, J.M. Phytochemical constituents, advanced extraction technologies and techno-functional properties of selected Mediterranean plants for use in meat products. A comprehensive review. Trends Food Sci. Technol. 2020, 100, 292-306. [CrossRef]

2. Lorenzo, J.M.; Pateiro, M.; Domínguez, R.; Barba, F.J.; Putnik, P.; Kovačević, D.B.; Shpigelman, A.; Granato, D.; Franco, D. Berries extracts as natural antioxidants in meat products: A review. Food Res. Int. 2018, 106, 1095-1104. [CrossRef]

3. Tulio, A.Z.; Reese, R.N.; Wyzgoski, F.J.; Rinaldi, P.L.; Fu, R.; Scheerens, J.C.; Miller, A.R. Cyanidin 3-rutinoside and cyanidin 3-xylosylrutinoside as primary phenolic antioxidants in black raspberry. J. Agric. Food Chem. 2008, 56, 1880-1888. [CrossRef]

4. Kanegusuku, M.; Sbors, D.; Bastos, E.S.; de Souza, M.M.; Cechinel-Filho, V.; Yunes, R.A.; Monache, F.D.; Niero, R. Phytochemical and analgesic activity of extract, fractions and a 19-hydroxyursane-type triterpenoid obtained from Rubus rosaefolius (Rosaceae). Biol. Pharm. Bull. 2007, 30, 999-1002. [CrossRef]

5. Ščetar, M.; Kurek, M.; Galić, K. Trends in fruit and vegetable packaging-A review. Croat. J. Food Technol. Biotechnol. Nutr. 2010, 5, 69-86.

6. Ponder, A.; Hallmann, E. The effects of organic and conventional farm management and harvest time on the polyphenol content in different raspberry cultivars. Food Chem. 2019, 301, 125295. [CrossRef] [PubMed]

7. Jianglian, D.; Shaoying, Z. Application of chitosan based coating in fruit and vegetable preservation: A review. J. Food Process. Technol. 2013, 4, 227. [CrossRef]

8. Yu, C.; Zeng, L.; Sheng, K.; Chen, F.; Zhou, T.; Zheng, X.; Yu, T. $\gamma$-Aminobutyric acid induces resistance against Penicillium expansum by priming of defence responses in pear fruit. Food Chem. 2014, 159, 29-37. [CrossRef]

9. Francis, G.A.; Gallone, A.; Nychas, G.J.; Sofos, J.N.; Colelli, G.; Amodio, M.L.; Spano, G. Factors Affecting quality and safety of fresh-cut produce. Crit. Rev. Food Sci. Nutr. 2012, 52, 595-610. [CrossRef]

10. Mastromatteo, M.; Conte, A.; Del Nobile, M.A. Combined use of modified atmosphere packaging and natural compounds for food preservation. Food Eng. Rev. 2010, 2, 28-38. [CrossRef]

11. Cota-Arriola, O.; Cortez-Rocha, M.O.; Burgos-Hernández, A.; Ezquerra-Brauer, J.M.; Plascencia-Jatomea, M. Controlled release matrices and micro/nanoparticles of chitosan with antimicrobial potential: Development of new strategies for microbial control in agriculture. J. Sci. Food Agric. 2013, 93, 1525-1536. [CrossRef]

12. Asghari, M.; Zahedipour, P. 24-epibrassinolide acts as a growth-promoting and resistance-mediating factor in strawberry plants. J. Plant Growth Regul. 2016, 35, 722-729. [CrossRef]

13. Dhakad, A.; Sonkar, P.; Bepari, A.; Kumar, U. Effect of pre-harvest application of plant growth regulators and calcium salts on biochemical and shelf life of acid lime (Citrus aurantifolia Swingle). J. Pharmacogn. Phytochem. 2020, 9, $1983-1985$.

14. Katiyar, D.; Hemantaranjan, A.; Singh, B.; Bhanu, A.N. A future perspective in crop protection: Chitosan and its oligosaccharides. Adv. Plants Agric. Res. 2014, 1, 1-8.

15. Castelo Branco Melo, N.F.; de Mendonçasoares, B.L.; Diniz, K.M.; Leal, C.F.; Canto, D.; Flores, M.A.; Henrique da Costa TavaresFilho, J.; Galembeck, A.; Stamford, T.L.M.; Stamford-Arnaud, T.M.; et al. Effects of fungal chitosan nanoparticles as eco-friendly edible coatings on the quality of postharvest table grapes. Postharvest Biol. Technol. 2018, 139, 56-66. [CrossRef]

16. Rinaudo, M. Chitin and chitosan: Properties and applications. Prog. Polym. Sci. 2006, 31, 603-632. [CrossRef]

17. Liu, J.; Zhang, J.; Xia, W. Hypocholesterolaemic effects of different chitosan samples in vitro and in vivo. Food Chem. 2008, 107, 419-425. [CrossRef]

18. Muzzarelli, R.A.; Boudrant, J.; Meyer, D.; Manno, N.; DeMarchis, M.; Paoletti, M.G. Current views on fungal chitin/chitosan, human chitinases, food preservation, glucans, pectins and inulin: A tribute to Henri Braconnot, precursor of the carbohydrate polymers science, on the chitin bicentennial. Carbohydr. Polym. 2012, 87, 995-1012. [CrossRef] 
19. Eshghi, S.; Hashemi, M.; Mohammadi, A.; Badii, F.; Mohammadhoseini, Z.; Ahmadi, K. Effect of nanochitosan-based coating with and without copper loaded on physicochemical and bioactive components of fresh strawberry fruit (Fragaria $x$ ananassa Duchesne) during storage. Food Bioprocess Technol. 2014, 7, 2397-2409. [CrossRef]

20. McClements, D.J.; Rao, J. Food-grade nanoemulsions: Formulation, fabrication, properties, performance, biological fate, and potential toxicity. Crit. Rev. Food Sci. Nutr. 2011, 51, 285-330. [CrossRef]

21. Acosta, E. Bioavailability of nanoparticles in nutrient and nutraceutical delivery. Curr. Opin. Colloid Interface Sci. 2009, 14, 3-15. [CrossRef]

22. Acevedo-Fani, A.; Soliva-Fortuny, R.; Martín-Belloso, O. Nanoemulsions as edible coatings. Curr. Opin. Food Sci. 2017, 15, 43-49. [CrossRef]

23. Chaudhary, S.; Kumar, S.; Kumar, V.; Sharma, R. Chitosan nanoemulsions as advanced edible coatings for fruits and vegetables: Composition, fabrication and developments in last decade. Int. J. Biol. Macromol. 2020, 152, 154-170. [CrossRef] [PubMed]

24. Bhargava, K.Y.; Aggarwal, S.; Kumar, T.; Bhargava, S. Comparative evaluation of the efficacy of three anti-oxidants vs. NaOCl and EDTA: Used for root canal irrigation in smear layer removal-SEM study. Int. J. Pharm. Pharm. Sci. 2015, 7, 366-371.

25. Zhang, L.; Li, J.; Hogan, S.; Chung, H.; Welbaum, G.E.; Zhou, K. Inhibitory effect of raspberries on starch digestive enzyme and their antioxidant properties and phenolic composition. Food Chem. 2010, 119, 592-599. [CrossRef]

26. Ponder, A.; Hallmann, E. The nutritional value and vitamin $C$ content of different raspberry cultivars from organic and conventional production. J. Food Compos. Anal. 2020, 87, 103429. [CrossRef]

27. Bazzocco, S.; Mattila, I.; Guyot, S.; Renard, C.M.G.C.; Aura, A.-M. Factors affecting the conversion of apple polyphenols to phenolic acids and fruit matrix to short-chain fatty acids by human faecal microbiota in vitro. Eur. J. Nutr. 2008, 47, 442-452. [CrossRef]

28. Horvitz, S. Postharvest Handling of Berries. Postharvest Handl. 2017, 107-123. [CrossRef]

29. Ayala-Zavala, J.F.; Wang, S.Y.; Wang, C.Y.; González-Aguilar, G.A. High oxygen treatment increases antioxidant capacity and postharvest life of strawberry fruit. Food Technol. Biotechnol. 2007, 45, 166-173.

30. Khademi, Z.; Ershadi, A. Postharvest application of salicylic acid improves storability of peach (Prunuspersicacv. Elberta) Fruits. Int. J. Agric. Crop Sci. 2013, 5, 651.

31. Vargas, M.; Albors, A.; Chiralt, A.; González-Martínez, C. Quality of cold-stored strawberries as affected by chitosan-oleic acid edible coatings. Postharvest Biol. Technol. 2006, 41, 164-171. [CrossRef]

32. Alirezalu, A.; Ahmadi, N.; Salehi, P.; Sonboli, A.; Alirezalu, K.; Khaneghah, A.M.; Barba, F.J.; Munekata, P.E.; Lorenzo, J.M. physicochemical characterization, antioxidant activity, and phenolic compounds of hawthorn (Crataegus spp.) fruits species for potential use in food applications. Foods 2020, 9, 436. [CrossRef] [PubMed]

33. Shin, Y.; Liu, R.H.; Nock, J.F.; Holliday, D.; Watkins, C.B. Temperature and relative humidity effects on quality, total ascorbic acid, phenolics and flavonoid concentrations, and antioxidant activity of strawberry. Postharvest Biol. Technol. 2007, 45, 349-357. [CrossRef]

34. Shameh, S.; Alirezalu, A.; Hosseini, B.; Maleki, R. Fruit phytochemical composition and color parameters of 21 accessions of five Rosa species grown in North West Iran. J. Sci. Food Agric. 2019, 99, 5740-5751. [CrossRef] [PubMed]

35. Nakajima, J.-I.; Tanaka, I.; Seo, S.; Yamazaki, M.; Saito, K. LC/PDA/ESI-MS Profiling and radical scavenging activity of anthocyanins in various berries. J. Biomed. Biotechnol. 2004, 2004, 241-247. [CrossRef] [PubMed]

36. Alirezalu, A.; Salehi, P.; Ahmadi, N.; Sonboli, A.; Aceto, S.; Maleki, H.H.; Ayyari, M. Flavonoids profile and antioxidant activity in flowers and leaves of hawthorn species (Crataegus spp.) from different regions of Iran. Int. J. Food Prop. 2018, 21, 452-470. [CrossRef]

37. Karthikeyan, M.; Radhika, K.; Mathiyazhagan, S.; Bhaskaran, R.; Samiyappan, R.; Velazhahan, R. Induction of phenolics and defense-related enzymes in coconut (Cocos nucifera L.) roots treated with biocontrol agents. Braz. J. Plant Physiol. 2006, 18, 367-377. [CrossRef]

38. Hassanpour, H. Effect of Aloe vera gel coating on antioxidant capacity, antioxidant enzyme activities and decay in raspberry fruit. LWT 2015, 60, 495-501. [CrossRef]

39. Gardesh, A.S.K.; Badii, F.; Hashemi, M.; Ardakani, A.Y.; Maftoonazad, N.; Gorji, A.M. Effect of nanochitosan based coating on climacteric behavior and postharvest shelf-life extension of apple cv. Golab Kohanz. LWT 2016, 70, 33-40. [CrossRef]

40. Lara, I.; Garcia, P.; Vendrell, M. Post-harvest heat treatments modify cell wall composition of strawberry (Fragaria $\times$ ananassa Duch.) fruit. Sci. Hortic. 2006, 109, 48-53. [CrossRef]

41. Gao, P.; Zhu, Z.; Zhang, P. Effects of chitosan-glucose complex coating on postharvest quality and shelf life of table grapes. Carbohydr. Polym. 2013, 95, 371-378. [CrossRef]

42. Salvia-Trujillo, L.; Rojas-Graü, M.A.; Soliva-Fortuny, R.; Martín-Belloso, O. Use of antimicrobial nanoemulsions as edible coatings: Impact on safety and quality attributes of fresh-cut Fuji apples. Postharvest Biol. Technol. 2015, 105, 8-16. [CrossRef]

43. Conforti, F.D.; Ball, J.A. A comparison of lipid and lipid/hydrocolloid based coatings to evaluate their effect on postharvest quality of green bell peppers. J. Food Qual. 2002, 25, 107-116. [CrossRef]

44. Hong, K.; Xie, J.; Zhang, L.; Sun, D.; Gong, D. Effects of chitosan coating on postharvest life and quality of guava (Psidium guajava L.) fruit during cold storage. Sci. Hortic. 2012, 144, 172-178. [CrossRef]

45. Bautista-Baños, S.; Hernández-López, M.; Bosquez-Molina, E.; Wilson, C. Effects of chitosan and plant extracts on growth of Colletotrichum gloeosporioides, anthracnose levels and quality of papaya fruit. Crop Prot. 2003, 22, 1087-1092. [CrossRef] 
46. Treviño-Garza, M.Z.; García, S.; Flores-González, M.D.S.; Arévalo-Niño, K. Edible active coatings based on pectin, pullulan, and chitosan increase quality and shelf life of strawberries (Fragaria ananassa). J. Food Sci. 2015, 80, M1823-M1830. [CrossRef]

47. Nair, M.S.; Tomar, M.; Punia, S.; Kukula-Koch, W.; Kumar, M. Enhancing the functionality of chitosan- and alginate-based active edible coatings/films for the preservation of fruits and vegetables: A review. Int. J. Biol. Macromol. 2020, 164, 304-320. [CrossRef]

48. Orzali, L.; Forni, C.; Riccioni, L. Effect of chitosan seed treatment as elicitor of resistance to Fusarium graminearum in wheat. Seed Sci. Technol. 2014, 42, 132-149. [CrossRef]

49. Hasan, S.M.K.; Ferrentino, G.; Scampicchio, M. Nanoemulsion as advanced edible coatings to preserve the quality of fresh-cut fruits and vegetables: A review. Int. J. Food Sci. Technol. 2019, 55, 1-10. [CrossRef]

50. Xing, K.; Zhu, X.; Peng, X.; Qin, S. Chitosan antimicrobial and eliciting properties for pest control in agriculture: A review. Agron. Sustain. Dev. 2015, 35, 569-588. [CrossRef]

51. Sivakumar, D.; Bautista-Baños, S. A review on the use of essential oils for postharvest decay control and maintenance of fruit quality during storage. Crop Prot. 2014, 64, 27-37. [CrossRef]

52. Chung, Y.-C.; Chen, C.-Y. Antibacterial characteristics and activity of acid-soluble chitosan. Bioresour. Technol. 2008, 99, 2806-2814. [CrossRef]

53. Krajewska, B.; Wydro, P.; Jańczyk, A. Probing the modes of antibacterial activity of chitosan. Effects of ph and molecular weight on chitosan interactions with membrane lipids in langmuir films. Biomacromolecules 2011, 12, 4144-4152. [CrossRef]

54. Verlee, A.; Mincke, S.; Stevens, C.V. Recent developments in antibacterial and antifungal chitosan and its derivatives. Carbohydr. Polym. 2017, 164, 268-283. [CrossRef]

55. Thumula, P. Studies on Storage Behaviour of Tomatoes Coated with Chitosan-Lysozyme Films. Ph.D. Thesis, McGill University, Montreal, QC, Canada, 2006.

56. Edwards, J.E.; Brown, P.N.; Talent, N.; Dickinson, T.A.; Shipley, P.R. A review of the chemistry of the genus Crataegus. Phytochemistry 2012, 79, 5-26. [CrossRef]

57. Dai, J.; Gupte, A.; Gates, L.; Mumper, R.J. A comprehensive study of anthocyanin-containing extracts from selected black-berry cultivars: Extraction methods, stability, anticancer properties and mechanisms. Food Chem. Toxicol. 2009, 47, 837-847. [CrossRef]

58. Baby, B.; Antony, P.; Vijayan, R. Antioxidant and anticancer properties of berries. Crit. Rev. Food Sci. Nutr. 2017, 58, $2491-2507$. [CrossRef] [PubMed]

59. Vámos-Vigyázó, L.; Haard, N.F. Polyphenol oxidases and peroxidases in fruits and vegetables. Crit. Rev. Food Sci. Nutr. 1981, 15, 49-127. [CrossRef]

60. Meng, X.; Li, B.; Liu, J.; Tian, S. Physiological responses and quality attributes of table grape fruit to chitosan preharvest spray and postharvest coating during storage. Food Chem. 2008, 106, 501-508. [CrossRef]

61. Sanchez-Gonzalez, L.; Pastor, C.; Vargas, M.; Chiralt, A.; Gonzalez-Martinez, C.; Chafer, M. Effect of hydroxypropylmethylcellulose and chitosan coatings with and without bergamot essential oil on quality and safety of cold-stored grapes. Postharvest Biol. Technol. 2011, 60, 57-63. [CrossRef]

62. Xu, W.T.; Peng, X.L.; Luo, Y.B.; Wang, J.A.; Guo, X.; Huang, K.L. Physiological and biochemical responses of grapefruit seed extract dip on "Redglobe" grape. LWT Food Sci. Technol. 2009, 42, 471-476. [CrossRef]

63. Jiang, Y.; Li, Y. Effects of chitosan coating on postharvest life and quality of longan fruit. Food Chem. 2001, 73, 139-143. [CrossRef]

64. Chaudière, J.; Ferrari-Iliou, R. Intracellular antioxidants: From chemical to biochemical mechanisms. Food Chem. Toxicol. 1999, 37, 949-962. [CrossRef]

65. Dar, T.A.; Uddin, M.; Khan, M.M.A.; Hakeem, K.; Jaleel, H. Jasmonates counter plant stress: A Review. Environ. Exp. Bot. 2015, 115, 49-57. [CrossRef]

66. Wang, J.; Wang, K.; Wang, Y.; Lin, S.; Zhao, P.; Jones, G. A novel application of pulsed electric field (PEF) processing for improving glutathione (GSH) antioxidant activity. Food Chem. 2014, 161, 361-366. [CrossRef]

67. Gill, S.S.; Tuteja, N. Reactive oxygen species and antioxidant machinery in abiotic stress tolerance in crop plants. Plant Physiol. Biochem. 2010, 48, 909-930. [CrossRef] [PubMed]

68. Hu, Q.; Hu, Y.; Xu, J. Free radical-scavenging activity of Aloe vera (Aloe barbadensis Miller) extracts by supercritical carbon dioxide extraction. Food Chem. 2005, 91, 85-90. [CrossRef]

69. Ishkeh, S.R.; Asghari, M.; Shirzad, H.; Alirezalu, A.; Ghasemi, G. Lemon verbena (Lippia citrodora) essential oil effects on antioxidant capacity and phytochemical content of raspberry (Rubus ulmifolius subsp. sanctus). Sci. Hortic. 2019, 248, 297-304. [CrossRef] 